удк 342.9

\title{
К.В. Слолов
}

\section{ОСКАРЖЕННЯ ПЛАТНИКОМ ПОДАТКІВ РІШЕНЬ КОНТРОЛЮЮЧИХ ОРГАНІВ У СУДОВОМУ ПОРЯДКУ: ОКРЕМІ ТЕОРЕТИЧНІ ТА ПРАКТИЧНІ ПРОБЛЕМИ}

Постановка проблеми. Конституцією України у статті 55 гарантоване право фізичних та юридичних осіб на судовий захист, за змістом якого кожному гарантується право на оскарження в суді рішень, дій чи бездіяльності органів державної влади, органів місцевого самоврядування, посадових і службових осіб [1]. Зазначене право деталізоване у пп. 17.1.7. п. 17.1. ст. 17 ПК України, де зазначено, що платник податків має право оскаржувати в порядку, встановленому цим Кодексом, рішення, дії (бездіяльність) контролюючих органів (посадових осіб), у тому числі індивідуальну податкову консультацію, яка йому надана, а також узагальнюючу податкову консультацію [3, ст. 17].

Поняття оскарження рішень контролюючих органів надано у пп. 14.1.7. п. 14.1. ст. 14 ПК України, відповідно до якої це оскарження платником податку податкового повідомлення-рішення про визначення сум грошового зобов'язання платника податків або будь-якого рішення контролюючого органу в порядку і строки, які встановлені цим Кодексом, за процедурами адміністративного оскарження або в судовому порядку [3, ст. 14]. Тобто під «рішеннями контролюючих органів» ПК України перш за все розуміє податкове повідомлення-рішення про визначення сум грошового зобов'язання та будь-які рішення контролюючого органу.

При цьому на законодавчому рівні відсутній навіть приблизний перелік «будьяких" рішень контролюючих органів, що можуть бути оскаржені у судовому порядку. Така невизначеність породжує досить великі межі судового розсуду щодо кола рішень контролюючих органів, які можуть бути оскаржені, або, навпаки, не можуть бути оскаржені в судовому порядку, та прямо впливає на ефективність судового захисту прав платників податків. Водночас такий перелік має бути невичерпним з огляду на динамічність податкового законодавства.

Яскравим прикладом є останні зміни в системі адміністрування податку на додану вартість, у зв'язку з якими до Податкового кодексу України та прийнятих на реалізацію його положень підзаконних актів було включено нові види рішень контролюючих органів, що відповідно можуть бути оскаржені як в адміністративному, так і в судовому порядку, а саме: рішення Комісії контролюючого органу регіонального рівня про включення платника податків до переліку ризикових платників податків, рішення Комісії регіонального або центрального рівня про відмову в реєстрації податкової накладної/розрахунку коригування.

Актуальність цього дослідження зумовлена насамперед досить великою кількістю податкових спорів, що розглядаються на теперішній час у порядку адміністративного судочинства. Так, за офіційною статистикою, розміщеною на веб-сайті Державної фіскальної служби, протягом січня-грудня 2018 року судами розглянуто 18,8 тис. справ на суму 61,3 млрд грн, з них: на користь органів ДФС - 11,75 тис. справ (у т.ч. немайнові спори) на суму 38,7 млрд грн, що становить $62,5 \%$ від кількості 
та $63,1 \%$ від суми розглянутих судами справ, та на користь платників податків 7,04 тис. справ на 22,6 млрд грн (або 37,5\% від кількості та 36,9\% від суми розглянутих справ). Із загальної кількості справ, що у січні-грудні 2018 року перебували на розгляді в судах різних інстанцій, одну з ключових категорій становили справи за позовами платників податків до органів ДФС про визнання недійсними/нечинними податкових повідомлень-рішень - 48,6 тис. справ на суму 200,5 млрд грн. Розглянуто 9,4 тис. справ на загальну суму 37,3 млрд грн, з них на користь органів ДФС - 3,8 тис. справ на 16 млрд гривень. При цьому у січні-грудні 2017 року (станом на 01.01.2018) на розгляді у судах різних інстанцій перебували: 47,1 тис. справ за позовами платників податків до територіальних органів ДФС про визнання недійсними/нечинними податкових повідомлень-рішень на загальну суму 182,3 млрд грн, 3 них на користь платників податків вирішено 4,7 тис. справ на суму на 20,3 млрд грн; 24 тис. справ за позовами органів ДФС до платників податків на загальну суму 53,1 млрд грн, з них на користь органів ДФС вирішено 10,2 тис. справ на суму 8,9 млрд гривень. Зазначені показники свідчать про тенденцію зростання кількості податкових спорів, а отже й про безумовну актуальність обраної для дослідження теми. Поява нових категорій податкових спорів викликана змінами у податковому законодавстві та появою нових видів рішень контролюючих органів, що є предметом оскарження платниками податків, додає актуальності тематиці дослідження та зумовлює необхідність виявлення проблемних питань у практиці застосування відповідних норм.

Мета цієї статті - дослідити правову природу окремих видів рішень контролюючих органів, що є предметом оскарження платниками податків, та окреслити проблемні питання у практиці вирішення окремих категорій податкових спорів; сформулювати пропозиції із вдосконалення окремих норм податкового законодавства та практики його застосування судами під час вирішення відповідних категорій податкових спорів.

Аналіз останніх досліджень і публікацій. Вивченню теоретичних та практичних питань вирішення податкових спорів присвячені роботи таких учених, як: Ю.В. Божко, А.Ю. Бучик, Д.О. Гетманцев, М.В. Жернаков, В.С. Кіценко, К.В. Конюшко, В.М. Кравчук, М.П. Кучерявенко, А.А. Роздайбіда, І.Л. Самсін, Є.А. Усенко, Д.М. Цвіра, Н.В. Шевцова, О.Ю. Щербакова та інших. Однак у своїх працях учені, як правило, фрагментарно висвітлювали проблемні питання судового оскарження тих чи інших рішень, дій чи бездіяльності контролюючих органів. Деякі з праць з огляду на плин часу та зміну підходів у правозастосуванні втратили свою актуальність. Водночас не можна оминути увагою праці вчених-адміністративістів I.О. Мандюк, В.П. Тимощука, присвячені юридичній природі індивідуальних адміністративних актів, висновки яких, безумовно, можуть бути враховані під час дослідження правової природи та структури рішень контролюючих органів. Аналіз останніх наукових досліджень та публікацій свідчить про те, що питання оскарження окремих видів рішень контролюючих органів не втрачає своєї актуальності, воно не піддавалось комплексному дослідженню з урахуванням практичних проблем правозастосування окремих податкових матеріально-правових та процесуально-правових норм Верховним Судом, що й спонукало автора здійснити спробу узагальнення сучасних правових позицій та поглядів науковців щодо правової природи окремих категорій рішень контролюючих органів, що є предметом відповідних видів податкових спорів. 
Виклад основного матеріалу. Д.В. Лученко цілком правильно зазначає, що предметом адмністративно-правового спору є рішення, дії або бездіяльність суб’єкта владних повноважень [32, с. 242].

Предметом податкового спору, за визначенням Д.М. Цвіри, є діяння (дія або бездіяльність, у тому числі прийняття податкового рішення), яке, на думку однієї зі сторін, порушує іï суб’єктивні права та інтереси, вчинене в межах податкових правовідносин та обмежене податковим і адміністративним процесуальним законодавством [41, с. 47]. В.С. Кіценко вважає, що предмет податкового спору становлять суб'єктивні права, юридичні обов'язки суб'єктів податкових правовідносин, а також законність правових актів контролюючих (податкових та митних) органів, що пов'язані зі встановленням або застосуванням податково-правових норм [30, с. 10].

Зміст статті 19 Кодексу адміністративного судочинства України (надалі - КАС України) дає змогу виокремити можливість оскарження рішень (нормативно-правових актів чи індивідуальних актів), дій чи бездіяльності суб'єктів владних повноважень загалом та контролюючих органів зокрема [2, ст. 19]. Тобто фактично можна вести мову про можливість оскарження платником податку:

- нормативно-правового акта контролюючого органу;

- індивідуального (ненормативного) акта контролюючого органу;

- дії контролюючого органу;

- бездіяльності контролюючого органу.

У науці адміністративного права визнається, що однією з найбільш поширених форм публічного адміністрування є видання індивідуальних адміністративних актів.

Професор І.Л. Самсін рішення податкових органів відносить до юридичних фактів як елемента механізму вирішення податкових спорів [37, с. 7].

Законодавче визначення поняття «індивідуальний адміністративний акт» міститься в п. 19 ч. 1 ст. 4 КАС України, згідно з якою індивідуальний акт - акт (рішення) суб'єкта владних повноважень, виданий (прийняте) на виконання владних управлінських функцій або в порядку надання адміністративних послуг, який стосується прав або інтересів визначеної в акті особи або осіб, та дія якого вичерпується його виконанням або має визначений строк [2, ст. 4].

Свого часу Конституційний Суд України в рішенні від 23.06.1997 року № 2-зп у справі про акти органів Верховної Ради України [4] та в рішенні від 16.04.2009 p. № 7-рп/2009 у справі про скасування актів органів місцевого самоврядування [5] зазначав, що ненормативні правові акти передбачають конкретні приписи, звернені до окремого суб'єкта чи юридичної особи, застосовуються одноразово і після реалізації вичерпують свою дію.

Порядок прийняття індивідуальних адміністративних актів передбачає наявність певної процедури.

В адміністративно-правовій науці натепер вживається термін «адміністративна процедура». Так, В.П. Тимощук вважає, що це встановлений законом (офіційно) порядок розгляду та вирішення адміністративними органами адміністративних справ, спрямований на прийняття адміністративного акта або укладення адміністративного договору [39, с. 56-57]. Адміністративна процедура, на думку В.П. Тимощука, являє собою саме зовнішне правозастосування у сфері державного управління [39, с. 62]. 
Схожої позиції стосовно відносин у сфері оподаткування дотримується професор М.П. Кучерявенко, виділяючи, зокрема, таке поняття, як «регулятивні податкові процедури» [31, с. 153-154].

При цьому М.П. Кучерявенко виділяє також охоронні податкові процедури та зазначає, що у процесі аналізу проблеми межі регулятивної з охоронною процедурою «таким моментом буде наявність або відсутність у поведінці платника податків дій, що дають змогу ставити питання про правопорушення під час виконання податкового обов'язку або спору» [31, с. 155].

Правозастосовча діяльність органів публічної адміністрації полягає у прийнятті адміністративних актів (індивідуальних актів управління), які є правозастосовчими актами в сфері державного управління [39, с. 62].

У теорії права є класифікація правозастосовних актів на регулятивні, охоронні та захисні. Перші офіційно підтверджують або визначають права й обов' язки сторін, викладені в диспозиції регулятивних норм, другі - офіційно попереджають конфлікти і суперечки, застосовують попереджальні заходи примусу, а треті - встановлюють міру юридичної відповідальності відповідно до санкції захисних норм, відновлюють порушене право [38, с. 431].

Податкове адміністрування є різновидом публічного адміністрування та являє собою, за визначенням проф. Д.О. Гетманцева, систему процедур реалізації прав і обов'язків суб'єктів податкового права щодо узгодження й погашення податкових зобов'язань [27, с. 74$]$.

Безумовно, в межах такої системи можна говорити про процедури прийняття контролюючими органами адміністративних актів, прийнятих на виконання покладених на такі органи завдань, метою прийняття яких здебільшого є саме узгодження та погашення податкових зобов’ язань.

I.О. Мандюк, у цілому погоджуючись з думкою В.П. Тимощука, виділяє такі стадії прийняття адміністративних актів:

- ініціювання та відкриття провадження;

- підготовка адміністративної справи до розгляду та вирішення;

- розгляд та вирішення адміністративної справи (прийняття адміністративного акта) [33, с. $127 ; 39$, с. 73].

При цьому науковцями зазвичай (але не без винятку) виокремлюються такі елементи будови (композиції) тексту правозастовних актів, що в цілому відповідають стадіям прийняття таких актів:

- вступна частина;

- мотивувальна частина (опис встановлених у справі юридично значущих фактів 3 посиланнями на джерела, що підтверджують докази; аналіз доказів; їх оцінка; юридична кваліфікація фактів; обгрунтування вибору правової норми, яка реалізується);

- результативна частина [38, с. 434].

Основним різновидом адміністративного акта, що застосовується контролюючими органами у разі донарахування сум податків, є податкове повідомлення-рішення (надалі - ППР).

Законодавче визначення такого рішення міститься у пп. 14.1.157 п. 14.1. ст. 14 ПК України, згідно з якою ППР - письмове повідомлення контролюючого органу 
(рішення) про обов'язок платника податків сплатити суму грошового зобов'язання, визначену контролюючим органом у випадках, передбачених цим Кодексом та іншими законодавчими актами, контроль за виконанням яких покладено на контролюючі органи, або внести відповідні зміни до податкової звітності [3, ст. 14].

За влучним твердженням М.О. Небесної, ППР можна віднести як до регулятивних адміністративних актів, так і до захисних з огляду на те, що ППР може прийматись не лише у зв'язку із застосуванням заходів впливу за результатами виявлених порушень податкового або іншого законодавства, контроль за дотриманням якого покладено на органи Державної фіскальної служби, але й у разі, коли згідно з податковим та іншим законодавством особою, відповідальною за нарахування сум податкових зобов'язань з окремого податку або збору, є контролюючий орган (пп. 54.3.3 п. 54.3. ст. 54 ПК України) [34, с. 121-122].

Стаття 58 ПК України містить загальні вимоги, яким має відповідати згадане рішення, та визначає, що форму та порядок надіслання ППР і розрахунку грошового зобов'язання визначає центральний орган виконавчої влади, що забезпечує формування та реалізує державну фінансову політику [3, ст. 58].

Із затвердженої Порядком надіслання контролюючими органами податкових повідомлень-рішень платникам податків [35] форми податкового повідомлення-рішення видається, що воно за своєю внутрішньою побудовою не містить такого структурного елемента, як мотивувальна частина.

На зазначену проблему звертає увагу також проф. Д.О. Гетманцев, зазначаючи, що «така форма ППР позбавляє суд можливості, виходячи зі змісту адміністративного акта, надати оцінку відповідності ППР одній з основних вимог згідно зі ст. 2 КАС України - обгрунтованості, а з іншого боку, зазначає вчений, суд під час розгляду відповідного позову платника податків фактично вимушений проводити повторну перевірку позивача, замінюючи собою орган виконавчої влади та виходячи за межі своїх повноважень» [28].

Погоджуючись у цілому з такою позицією, варто звернути увагу також і на те, що будь-яке ППР відповідно до затвердженої форми містить посилання на акт перевірки, що в подальшому став підставою для винесення того чи іншого ППР.

За змістом Порядку оформлення результатів документальних перевірок дотримання законодавства України з питань державної митної справи, податкового, валютного та іншого законодавства платниками податків - юридичними особами та їх відокремленими підрозділами акт документальної перевірки - службовий документ, який підтверджує факт проведення документальної перевірки, відображає їі результати і є носієм доказової інформації про виявлені порушення вимог законодавства з питань державної митної справи, податкового, валютного та іншого законодавства, контроль за дотриманням якого покладено на контролюючі органи [36, п. 2].

3 викладеного вище видається, що процедура прийняття ППР як адміністративного акта фактично не містить такої стадії, як розгляд та вирішення справи по суті, оскільки саме цій стадії, на переконання В.П.Тимощука, притаманний такий важливий її елемент (етап), як обгрунтування (мотивування) адміністративного акта. Але, як видається з наведеного, цей елемент чітко проявляється саме на стадії проведення перевірки та оформлення іiї результатів, у зв’язку з чим є всі підстави вважати, що 
проведення перевірки та оформлення її результатів є саме етапами розгляду однієї юридичної справи (прийняття адміністративного акта).

Фактично акт документальної перевірки за своїм змістом містить аналіз досліджених у конкретній юридичній ситуації доказів, їх оцінку та правову кваліфікацію допущеного платником податку порушення, а тому може, на думку автора, вважатись тією мотивувальною частиною ППР, якої не вистачає, на думку професора Д.О. Гетманцева. Однак наразі податкове законодавство не містить прямої вказівки на це, у зв’язку з чим немає підстав вважати ППР та акт перевірки єдиним рішенням, що, на переконання автора, потребує внесення відповідних змін до ПК України.

Окремої уваги в контексті проблеми, що розглядається, заслуговують висновки Верховного Суду, викладені в постанові від 22.08.2018 р. у справі № 812/1283/17 (адміністративне провадження №К/9901/46056/18), про те, що здійснення перевірки є необхідною передумовою для винесення податкових повідомлень-рішень у разі встановлення контролюючим органом порушень податкового та іншого законодавства, дотримання якого контролюється податковими органами, тому за відсутності проведеної перевірки як юридичного факту у контролюючого органу відсутня компетенція на винесення податкового повідомлення-рішення. Така компетенція не виникає через сам лише факт вчинення платником податків податкового правопорушення. Для визначення контролюючим органом грошових зобов'язань платникові податків шляхом прийняття податкового повідомлення-рішення у зв'язку з допущеними таким платником порушеннями необхідно дотриматися певних умов, а саме спочатку провести податкову перевірку [18].

Необхідність включення акта перевірки до складу ППР як невід’ємного складника, а також обов'язковість винесення ППР за наслідками перевірки підтверджується судовою практикою щодо неможливості оскарження дій контролюючого органу 3 проведення документальної перевірки та висновків, викладених в акті перевірки (наприклад, постанова ВС від 06.02.2018 р. у справі № 810/7195/14 та від 13.02.2018 р. у справі № 804/5402/14) [7; 8].

Водночас за усталеною правозастосовчою практикою безпосередньо акт податкової перевірки не може бути предметом оскарження, оскільки не відповідає критерію юридичної значимості, тобто є документом, що не створює юридичних прав та обов'язків для платника податків. Схожої позиції дотримуються окремі науковці, наприклад Є.А. Усенко, яка зазначає, що основним для визначення можливості вирішення спору із застосуванням судової процедури є відповідність оскаржуваного рішення чи дії акта правозастосування, а бездіяльності - перешкоді правозастосуванню щодо встановлення (зміни, скасування) суб'єктивних прав і обов’язків персоніфікованих суб'єктів податкових правовідносин, у зв' язку з чим не підлягають розгляду в суді позови платників податків стосовно правомірності актів перевірок, здійснених податковим органом, наказів посадових осіб податкових органів про проведення перевірок (планових або позапланових), оскільки вони не є актами правозастосування стосовно платника податків, а належним способом захисту права чи законного інтересу у цих випадках буде позов про скасування податкового повідомлення-рішення, прийнятого на підставі акта перевірки, та недопущення платником службових осіб податкового органу до проведення перевірки, призначеної з порушенням закону [40, с. 123-124]. 
Крім того, в постанові Верховного Суду від 04.09.2018 р. у справі № 810/3676/14 (адміністративне провадження №К/9901/4502/18) зазначено, що висновки, викладені в акті перевірки, є відображенням дій працівників органів доходів і зборів і самі собою не породжують правових наслідків для платника податків та, відповідно, такий акт не порушує прав останнього [19]. Водночас у постанові від 18.09 .2018 р. у справі № 820/15224/14 (адміністративне провадження № К/9901/9298/18) Верховний Суд дійшов висновку, що акт перевірки $є$ виключно носієм доказової інформації про виявлені податковим органом порушення вимог податкового, валютного та іншого законодавства платниками податків, обов'язковим документом, на підставі якого приймається відповідне рішення контролюючого органу. Контролюючий орган не позбавлений права викладати в акті перевірки власні суб'єктивні висновки щодо зафіксованих обставин та в майбутньому (у разі виникнення спору щодо рішень про визначення податкових зобов'язань) обґрунтовувати ними власну позицію щодо наявності певних допущених платником податків порушень [20]. Але в цьому контексті варто також згадати постанову Верховного Суду України від 24.01.2006р., в якій було зазначено, що суд може захистити право платника податку в разі проведення перевірки за відсутності для цього належних юридичних підстав та з порушенням правил, процедури, встановлених законом. Наявність негативних наслідків такої перевірки для можливості судового захисту законом не вимагається. Право на судовий захист пов'язане із самою протиправністю дій. Обраний позивачем спосіб захисту порушеного права - визнання відсутності права на перевірку - $€$ нічим іншим як вимогою про визнання неправомірною позапланової комплексної перевірки, тобто дій органу державної податкової служби. Право особи на таку вимогу, такий спосіб захисту порушеного права ґрунтується на положеннях чинного законодавства, зокрема ст. 20 ГК України, яка встановлюе і такий спосіб захисту, як припинення дій, що порушують право або створюють загрозу його порушення. У зв'язку із зазначеним Верховний Суд України вказав на помилковість висновку суду апеляційної інстанції про те, що права і законні інтереси суб'єкта господарювання у правовідносинах з органами державної податкової служби захищаються лише шляхом визнання недійсними актів цих органів [6]. Проте натепер така правова позиція, на жаль, не знайшла прихильників у новоствореному Верховному Суді.

Але водночас Верховний Суд неодноразово звертав увагу контролюючих органів на необхідність дотримання відповідності прийнятих ним рішень такому критерію, як обгрунтованість.

Так， Верховним Судом у постановах від 23.10 .2018 р. у справі № 822/1817/18 (адміністративне провадження № К/9901/62472/18) [22] та від 04.12.2018 p. у справі № 821/1173/17 (адміністративне провадження № К/9901/62719/18) [25] під час розгляду спорів про зупинення реєстрації податкових накладних було сформовано правовий висновок, відповідно до якого надання податковому органу відповідних повноважень - це лише передумова подальшої реалізації його управлінських функцій, результатом реалізації чого є прийняття відповідного рішення, законність якого може бути перевірена адміністративним судом. Загальними вимогами, які висуваються до актів індивідуальної дії як акта правозастосування, є його обг рунтованість ma вмотивованість, тобто наведення податковим органом конкретних підстав його 
прийняття (фактичних і юридичних), а також переконливих і зрозумілих мотивів його прийняття. Отже, невиконання податковим органом законодавчо встановлених вимог щодо змісту, форми, обгрунтованості та вмотивованості акта індивідуальної дії призводить до його протиправності.

Окремий блок проблем становить оскарження податкових повідомлень-рішень, винесених за результатами камеральних перевірок, предметом яких було дослідження питань, що виходять за межі такої перевірки, але, на жаль, обсяг цієї публікації не дає можливості висвітлити всі проблемні питання, що виникають під час оскарження ППР.

Таким чином, з метою забезпечення ефективного судового захисту прав платників податків та більш прозорого публічного адміністрування у сфері оподаткування негайного законодавчого удосконалення потребує структура такого адміністративного акта контролюючого органу, як податкове повідомлення-рішення, шляхом внесення відповідних змін до ПК України.

Одними з найбільш поширених поряд з податковими повідомленнями- рішеннями адміністративними актами контролюючих органів, що оскаржуються платниками податків, є накази про призначення перевірок.

Податковий кодекс України не містить легальної дефініції поняття «наказ про проведення перевірки». Водночас системний аналіз положень п. 77.4. ст. 77, п. 78.4. ст. 78, п. 79.2. ст. 79, п. 80.2. ст. 80, п. 81.1. ст. 81 ПК України дає підстави для висновку про те, що наказ про проведення перевірки є рішенням контролюючого органу про проведення відповідного виду перевірки (документальна планова, документальна позапланова невиїзна або виїзна, фактична), прийнятим керівником (його заступником або уповноваженою особою) контролюючого органу за наявності підстав, визначених ПК України, в якому зазначаються дата видачі, найменування контролюючого органу, найменування та реквізити суб’єкта, перевірка якого проводиться, мета, вид, підстави, дата початку і тривалість перевірки, період діяльності, який буде перевірятися, та інші реквізити, передбачені ПК України, та який скріплюється підписом особи, що його прийняла та печаткою контролюючого органу.

Аналіз судової практики свідчить про неоднозначність правозастосування в питаннях оскарження наказів про призначення різних видів перевірок.

Так, наприклад, у правозастосовчій практиці натепер відсутня єдина позиція щодо можливості оскарження наказу про призначення податкової перевірки. В одному випадку (постанова від 02.05.2018 р. у справі № 804/3006/17) Верховний Суд визнає за платником податків право на оскарження такого наказу [12], зазначаючи, що з наказом про перевірку, відомостями про дату її початку та місце проведення платник має бути ознайомлений у встановлений законом спосіб до її початку, а невиконання цих вимог призводить до визнання перевірки незаконною та відсутності правових наслідків такої. Однак в інших аналогічних випадках Верховний Суд (постанова від 13.03.2018 р. у справі № 804/1113/16) вказує, що позови платників податків, спрямовані на оскарження рішень (у тому числі наказів про призначення перевірки), дій або бездіяльності контролюючих органів щодо призначення та/або проведення перевірок можуть бути задоволені лише в тому разі, якщо до моменту винесення судового рішення не відбулося допуску посадових осіб контролюючого органу до спірної перевірки. 
В іншому разі в задоволенні відповідних позовів має бути відмовлено, оскільки правові наслідки оскаржуваних дій за таких обставин є вичерпаними, а отже, задоволення позову не може призвести до відновлення порушених прав платників податків, оскільки після проведення перевірки права платника податків порушують лише наслідки проведення відповідної перевірки [10]. Крім того, прихильники останньої позиції на їі обгрунтування наводять такі доводи. Наказ є актом одноразового застосування та вичерпує свою дію фактом його виконання, а отже, задоволення позову не може призвести до відновлення порушених прав платника податків. А за результатами реалізації прав, що випливають із вказаного наказу, податковим органом складено не лише акт перевірки, а й прийняті податкові повідомлення-рішення. Отже, податковим органом фактично була реалізована його компетенція на проведення перевірки та оформлення результатів такої перевірки, у зв’язку з чим оспорюваний наказ не є таким, що порушує права позивача та інтереси шляхом обмежень у реалізації його прав чи безпідставного покладення на нього необгрунтованих обов'язків, а отже, задоволення позовної вимоги про визнання протиправним та скасування наказу не призведе до поновлення порушеного права позивача, оскільки, по-перше, такий наказ контролюючого органу не є юридично значимим для платника податку, по-друге, після проведення перевірки права платника податків порушують лише наслідки проведення відповідної перевірки (постанова Верховного Суду від 07.11.2018 р. у справі № П/811/824/17 (провадження № К/9901/31381/18) [23].

На жаль, це не єдиний приклад різного розуміння судовими органами змісту поняття «рішення контролюючого органу», «адміністративний акт» та правових наслідків визнання його протиправним та скасування.

Доцільним, на нашу думку, є висвітлення інших проблемних питань щодо оскарження наказів про призначення податкових перевірок, а саме слід звернути увагу на призначення документальних планових перевірок.

Так, останнім часом контролюючі органи розпочали практикувати коригування плану-графіка перевірок у поточному році, а окрім цього, здійснюють формування плану-графіка перевірок без дотримання принципу ризиковості діяльності платника податків.

Прикладом може бути постанова Верховного Суду від 27.11.2018 р. у справі № 821/1759/17 (провадження №К/9901/63522/18), в якій суд касаційної інстанції зауважив, що з аналізу норм п. 77.2. ст. 77 ПК України та Порядку формування плану-графіка проведення документальних планових перевірок платників податків, затвердженого наказом Міністерства фінансів України від 02.06.2015 р. № 524 (зареєстровано в Міністерстві юстиції України 24.06.2015 р. за № 751/27196), план-графік проведення перевірок на відповідний квартал має формуватись у визначені терміни та включати платників податків, які мають найбільші критерії ризику, визначені у відповідності до вищевказаного Порядку, у тому числі за даними інформаційних систем ДФС. Таким чином, до предмета доказування у цій категорії справ входить не лише дослідження наявності або відсутності плану-графіка на відповідний період і включення до нього конкретного платника податків, але й перевірка того, чи був відповідний план-графік складений з дотриманням визначених строків, чи наявні підстави включення позивача до плану-графіка та чи дотримано процедуру такого включення [24]. 
В інших судових рішеннях Верховний Суд також зазначає, що законодавцем запроваджено ризикоорієнтований підхід до планування перевірок платників податків з урахуванням особливостей критеріїв суб'єктів господарювання за ступенями ризику їхньої господарської діяльності, періодичності проведення планових заходів та переліку питань для їх здійснення. Тобто платник податків включається до плану-графіка проведення перевірок залежно від ступеня ризику в діяльності такого платника податків (постанова від 31.07.2018 р. у справі № 820/653/17 (провадження № К/9901/39717/18) [15] та постанова від 22.08.2018 р. у справі № 826/7988/17 (провадження № К/9901/2007/18) [17].

3 теоретичної точки зору вказані проблеми мають розглядатись під кутом розсуду у податковому правозастосуванні та дотримання балансу публічних та приватних інтересів. У таких категоріях спорів суд фактично перевіряє дотримання принципів розумності та обгрунтованості під час застосування розсуду контролюючим органом.

Погоджуємось 3 дефініцією розсуду у податковому правозастосуванні, наданою І.Л. Желтобрюх, як визначеною рамками законодавства про податки і збори свободи вибору уповноваженого правозастосовчого органу (податкового, митного органу) під час прийняття суб’єктивно-оптимального рішення, що зумовлена поставленими перед ним завданнями, відповідає інтересам держави і суспільства і грунтується на встановлених об'єктивних обставинах [29, с. 65].

При цьому розсудом, на думку І.Л. Желтобрюх, не може вважатися будь-яка мисленнєво-аналітична діяльність суб'єкта правозастосування, а тільки така, що виникає у зв'язку з наявністю прогалин у праві, колізій нормативно-правових приписів, оціночних понять [29, с. 54].

3 точки зору розсуду дуже цікавими також є практичні питання призначення документальних позапланових перевірок на підставі пп.78.1.1, 78.1.4 п. 78.1. ст. 78 ПК України. У таких спорах податковий конфлікт виникає, як правило, через різне сприйняття його сторонами фактів, які свідчать про наявність підстав для направлення контролюючим органом запиту про надання пояснень та їх документального підтвердження в порядку статті ст. 73 ПК України, ненадання відповіді на такий запит або надання неповної відповіді може бути відповідно підставою для призначення документальної позапланової перевірки. Тобто суд у такій категорії податкових спорів також фактично здійснює перевірку обґрунтованості застосування розсуду контролюючим органом під час призначення документальної позапланової перевірки.

Так, у постанові від 27.03 .2018 р. у справі № 813/2162/17 (провадження № К/9901/5143/18) Верховний Суд зазначає, що запит є формою реалізації владних управлінських функцій податковим органом як суб'єктом владних повноважень, $\epsilon$ формою взаємодії між контролюючим органом та платником податків, спрямований на належне виконання контрольної функції держави щодо належного обчислення та сплати податків, та запобігання вчинення податкових правопорушень суб'єктами господарювання, підстави, умови та порядок направлення якого визначені Податковим кодексом України. Наказ контролюючого органу про проведення перевірки має містити в собі як підставу іï проведення посилання на неотримання пояснень від платника податку та їх документальних підтверджень на обов'язковий письмовий запит контролюючого органу щодо виявлених обставин, визначених таким запитом. Аналіз по- 
ложень податкового законодавства свідчить про те, що запит податкового органу про надання відповідної інформації платником податків має визначати конкретні підстави, тобто наявність чітко окреслених обставин, які свідчать про порушення платником податків податкового законодавства. Без повідомлення вказаних фактів платник податків не має об’єктивної можливості надати будь-які пояснення та їх документальне підтвердження [11].

Натомість у постанові від 22.05.2018 р. у справі № 820/4605/17 (провадження №К/9901/30642/18) Верховний Суд наголосив, що змістова конструкція пп. 78.1.1 п. 78.1 ст. 78 ПК України (який викладено в новій редакції з урахуванням внесених змін Законом України від 21 грудня 2016 року № 1797-VIII «Про внесення змін до Податкового кодексу щодо покращення інвестиційного клімату в Україні», яку доповнено змістом, що дає можливість проведення позапланової перевірки також у разі отримання податкової інформації, яка свідчить про порушення вимог податкового законодавства) зумовлює наявність інформації як такої, що допускає порушення, але необов'язково. Внаслідок отримання такої інформації виникає обґрунтована та законодавчо встановлена необхідність для контролюючого органу зі здійснення належного податкового контролю. Належною формою реалізації такого обов'язку є спрямування письмового запиту до платника податків із зазначенням у запиті про наявні порушення з боку такого платника та необхідність надання ним пояснень та документів. Метою запиту є підтвердження або спростування тієї інформації, яка $€$ у податкового органу, при чому достовірність такої інформації про порушення може бути як категорична, так і умовна. Встановлення порушення та формування висновків про це можливе лише після отримання запитуваної контролюючим органом інформації. Тому наведення у запиті з посиланням на інформацію, як можливого порушення, а не категоричного висновку про порушення з боку платника податків, передбачає наявність інформації, яка потребує додаткової перевірки, яку можливо реалізувати шляхом здійснення запиту та проведеного аналізу після її отримання. У разі якщо платник податків не надасть пояснення та їх документальні підтвердження на обов'язковий письмовий запит контролюючого органу, протягом 15 робочих днів з дня, наступного за днем отримання запиту, у податкового органу є підстави для іï призначення. Вказівка позивача на окремі дефекти запиту про надання інформації і наказу про призначення податкової перевірки для вирішення оспорюваного питання значення не має, оскільки відповідно до усталеної судової практики, зокрема, відсутність або неповнота посилань на конкретні пункти Кодексу не мають розглядатися як підстава для визнання наказу протиправним, якщо зі змісту такого наказу видається за можливе ідентифікувати передбачену законодавством фактичну підставу для призначення відповідної перевірки. Фактичною підставою для проведення позапланової виїзної перевірки позивача стало ненадання ним пояснень та їх документального підтвердження на обов'язкові письмові запити. Письмові запити щодо необхідності подання пояснень сформовані податковим органом на підставі інформації з інформаційних систем автоматизованого моніторингу [13].

У цілому схожий, але трохи інакший висновок сформовано Верховним Судом у постанові від 28.02.2019 р. у справі № 820/4437/18 (провадження № К/9901/66147/18), відповідно до якого за наслідками аналізу доводів позивача 
про відсутність у податкового органу інформації щодо порушення платником податку законодавства зазначено, що запит контролюючого органу про надання платниками податків податкової інформації надсилається у разі обгрунтованого сумніву (підтвердженого отриманою у встановленому законом порядку інформацією) податкового органу щодо дотримання платником податку вимог законодавства та з метою надання можливості платникам податків усунути такі сумніви поясненнями та документами, які підтверджують такі пояснення, для спростування висновків податкового органу про ймовірні порушення. У разі ненадання відповіді та запитуваної інформації на запит контролюючого органу, що оформлений у відповідності до норм Податкового кодексу України, у податкового органу відсутня можливість перевірити отриману інформацію про можливі порушення платниками податків податкового законодавства, наслідком чого є призначення перевірки у встановленому Податковим кодексом України порядку. Таким чином, наявність у податкового органу податкової інформації, що вказує про ймовірні порушення позивачем вимог податкового законодавства, не свідчить беззаперечно про те, що такі порушення мають місце. Задля можливості спростувати таку інформацію і надсилається запит податкового органу. Посилання позивача на окремі дефекти запиту про надання інформації не впливають на обов'язок позивача надати всю необхідну інформацію за запитом, оскільки відсутність або неповнота посилань на конкретні джерела отримання податкової інформації не мають розглядатися як підстава для визнання запиту таким, що не відповідає вимогам п. 73.3 ПК України, та, як наслідок, бути підставою для визнання наказу про проведення податкової перевірки протиправним [26].

У постанові від 01.08.2018 р. у справі № 804/2071/15 (провадження № К/9901/28754/18) Верховний Суд робить висновок, що документальна позапланова перевірка проводиться на підставі наказу керівника контролюючого органу та за наявності підстав для її проведення; своєю чергою можливість для прийняття наказу про проведення документальної позапланової перевірки на підставі пп. 78.1.1 п. 78.1 ст. 78 ПК України виникає за наявності таких умов: виявлення фактів, що свідчать про порушення платником податків податкового, валютного та іншого законодавства, контроль за дотриманням якого покладено на контролюючі органи; ненадання платником пояснень та їх документального підтвердження на запит контролюючого органу протягом 10 робочих днів з дня отримання запиту. Зазначені у пп. 78.1.1 п. 78.1 ст. 78 ПК України обставини є юридичним фактом, з настанням якого законодавець пов'язує подальшу реалізацію контролюючим органом свого права на проведення документальної позапланової перевірки. При цьому факти, які свідчать про порушення платником податків податкового, валютного та іншого законодавства, контроль за дотриманням якого покладено на контролюючі органи, можуть бути підставою для проведення перевірки лише у разі, коли сумніви не усунуті наданими поясненнями та їх документальними підтвердженнями. За таких обставин у контролюючого органу є право на оцінку пояснень і їх докулентальних підтверджень. Якщо иі пояснення не обг рунтовані або документально не підтверджені, перевірка може бути призначена. Суб'єкт господарювання має право не погодитися з рішенням про призначення перевірки й оспорити його у суді. У такому спорі суб'єкт владних повноважень зобов'язаний довести обгрунтованість свого рішення з посиланням на недоліки пояснень 
суб’єкта господарювання та їх документальне обгрунтування. Аналогічна правова позиція була висловлена колегією суддів Судової палати в адміністративних справах Верховного Суду України, зокрема, у постанові від 16 лютого 2016 року (справа № 826/12651/14) [16].

Водночас, на думку І.Л. Желтобрюх, одним із засобів, які сприяють обмеженню негативного розсуду в податковому правозастосуванні, регулюють межі розсуду, можуть бути судові доктрини [29, с. 90].

Але, як видається з наведених вище прикладів судової практики та оцінки судами законності застосування розсуду контролюючим органом під час формування запитів про надання пояснень та їх документальних підтверджень, має місце сформована судова доктрина, відповідно до якої платник податків має спростовувати припущення податкового органу про наявність допущених порушень норм податкового, валютного або іншого законодавств, контроль за яким покладається на відповідні органи, наслідком чого є надання фактичної можливості контролюючому органу призначити документальну позапланову перевірку в будь-якому необхідному разі, що, на нашу думку, не відповідає презумпції правомірності рішень платників податків.

Досить велике коло питань, які з огляду на обсяг цієї публікації не можуть бути висвітлені більш детально, становлять спори щодо призначення документальних позапланових перевірок на підставі пп. 78.1.11. п. 78.1. ст. 78 ПК України у разі, якщо отримано судове рішення суду (слідчого судді) про призначення перевірки, винесене ними відповідно до закону. Проте судова практика в цьому напрямі знаходить більш усталений підхід, виходячи з відсутності закріпленого кримінальним процесуальним законом порядку звернення та розгляду клопотань про призначення перевірок.

Серед розмаїття адміністративних актів податкових органів, що можуть бути предметом оскарження, на окрему увагу заслуговує такий нетиповий правозастосовчий акт, як індивідуальна податкова консультація.

Так, відповідно до положень пп. 14.1.172-1. п. 14.1. ст. 14 ПК України індивідуальна податкова консультація - роз'яснення контролюючого органу, надане платнику податків щодо практичного використання окремих норм податкового та іншого законодавства, контроль за дотриманням якого покладено на контролюючий орган, та зареєстроване в єдиному реєстрі індивідуальних податкових консультацій [3, пп. 14.1.172-1. п. 14.1. ст. 14].

За слушним зауваженням І.Л. Желтобрюх, податкова консультація як об’єктивований вираз первинного розсуду є своєрідною правовою позицією контролюючого органу щодо порядку застосування норми права, яка стала об'єктом розсуду [29, с. 32].

За змістом п. 53.2. ст. 53 ПК України платник податків може оскаржити до суду наказ про затвердження узагальнюючої податкової консультації або надану йому індивідуальну податкову консультацію як правовий акт індивідуальної дії, викладені в письмовій формі, які, на думку такого платника податків, суперечать нормам або змісту відповідного податку чи збору [3, п. 53.2. ст. 53].

Проте свого часу серед практиків не було єдності думок щодо можливості оскарження таких нестандартних рішень контролюючих органів з огляду на те, що вони нібито не зачіпали прав платників податків, у зв’язку з чим такі податкові спори вирішувались неоднозначно. 
Однак Верховний Суд у постанові від 16.10 .2018 р. у справі № 820/4461/17 (провадження № К/9901/3725/17) на підставі системного аналізу наведених вище норм дійшов висновку, що податкова консультація за своєю правовою природою $€$ фактично відповіддю контролюючого органу платнику податків на його питання, яка має містити конкретні роз'яснення такому платнику практичної форми та/або моделі його поведінки у визначеному колі податкових правовідносин, та у разі невідповідності правовій сутності така податкова консультація підлягає скасуванню [21].

У постанові від 20.02.2018 р. у справі № 813/2617/15 (адміністративне провадження № К $/ 9901 / 8571 / 18)$ Верховний Суд звернув увагу на помилковість висновків судів попередніх інстанцій про те, що надана контролюючим органом податкова консультація не створює і не припиняє прав чи обов'язків позивача, оскільки (серед іншого) отримання позивачем індивідуальної податкової консультації, зміст якої відповідає нормам чинного законодавства, є юридичним фактом, що є підставою для звільнення від відповідальності платника податку, який діяв у відповідності до наданих такою консультацією роз'яснень з питань практичного застосування окремих норм податкового законодавства. Таким чином, ПК України чітко врегульовано правовий статус податкової консультації як акта індивідуальної дії, який з огляду на ст. 19 КАС України може бути предметом судового оскарження в порядку адміністративного судочинства. При цьому дослідженню в справах про визнання протиправною та скасування податкової консультації підлягають обставини щодо: поставлених у зверненні платника податків про надання податкової консультації питань; викладених у податковій консультації відповідей; відповідності зазначених у податковій консультації висновків нормам або змісту відповідного податку чи збору [9].

Крім того, в аспекті обрання належного способу захисту порушеного права Верховний Суд у постанові від 12.06.2018 р. у справі № 814/2168/16 (адміністративне провадження №К/9901/37755/18) звернув увагу на те, що порушене право платника податків внаслідок отримання податкової консультації, яка суперечить нормам або змісту відповідного податку чи збору, є відновленим шляхом визнання протиправною та скасування такої консультації. Оскільки наведене є підставою для надання контролюючим органом нової консультації, то окреме заявлення позовної вимоги про зобов'язання контролюючого органу надати нову консультацію є передчасним [14].

Досліджуючи природу податкової консультації, І.Л. Желтобрюх зазначає, що фактично контролюючі органи у сфері оподаткування беруть на себе виконання функцій, пов'язаних з тлумаченням норм податкового законодавства України, хоча в диспозиції п. 52.1. зазначається, що податкові консультації стосуються лише «практичного використання окремих норм податкового законодавства», але, на думку вченої, давати практичні поради щодо використання норм, не торкаючись тлумачення їх змісту, неможливо. Такий підхід законодавця щодо врегулювання імперативних податкових правовідносин викликає у авторки певні сумніви насамперед тому, що, як випливає зі змісту ст. 52 ПК України, на контролюючі органи фактично покладаються повноваження, які їм належати не можуть [29, с. $12 ; 36]$.

Справді, загалом погоджуючись з позицією І.Л. Желтобрюх, варто додати, що у разі непогодження з наданою податковою консультацією платник податків напідставі 
ст. 53 ПК України може оскаржити їі до суду. Скасування судом наказу про затвердження узагальнюючої податкової консультації або індивідуальної податкової консультації є підставою для надання нової податкової консультації з урахуванням висновків суду [3, п. 53.2. ст. 53]. Отже, саме суд у такому разі буде надавати оцінку, як відзначено вище, відповідності зазначених у податковій консультації висновків нормам або змісту відповідного податку чи збору, тобто здійснювати не властиву адміністративному суду функцію суду конституційної юрисдикції.

Висновки. Результати викладеного вище дослідження дали змогу автору сформувати такі висновки.

1. Будь-який індивідуальний адміністративний акт контролюючого органу, у тому числі податкове повідомлення-рішення, задля відповідності критерію обгрунтованості має відповідати структурі правозастосовчого акта: вступна, описова, мотивувальна, резолютивна частини.

2. Процедура прийняття ППР як адміністративного акта не містить такої стадії, як розгляд та вирішення справи по суті, якій притаманний такий важливий елемент (етап), як обгрунтування (мотивування) адміністративного акта.

3. ППР як індивідуальний адміністративний акт не містить такого складового елемента, як мотивувальна частина, що потребує приведення податкового законодавства у відповідність до вказаних вимог з огляду на необхідність дотримання критерію обгрунтованості під час прийняття відповідних рішень.

4. Акт перевірки не може бути самостійним предметом оскарження платником податків, оскільки не є актом правозастосування та не відповідає критерію юридичної значимості, тобто не впливає на обсяг прав та обов'язків платника податків, однак він є передумовою для прийняття контролюючим органом відповідного рішення або вчинення іншої дії та відповідно відсутні перешкоди для визнання акта перевірки мотивувальною частиною ППР. Більше того, акт документальної перевірки за своїм змістом містить аналіз досліджених у конкретній юридичній ситуації доказів, їх оцінку та правову кваліфікацію допущеного платником податку порушення, а відтак фактично є мотивувальною частиною ППР.

5. Обгрунтованість ППР та іншого індивідуального адміністративного акта контролюючого органу є одним із критеріїв, визначених ч. 2 ст. 2 КАС України, який перевіряється адміністративним судом у справах про оскарження рішень суб'єктів владних повноважень та полягає у обов'язковості наведення податковим органом конкретних підстав прийняття відповідного рішення (фактичних і юридичних), а також переконливих і зрозумілих мотивів його прийняття.

7. Доцільним є внесення до ПК України легальної дефініції «наказ про призначення перевірки», а також доповнення ПК України положеннями щодо визначення моменту вичерпання дії наказу про проведення перевірки з метою формування єдиної позиції щодо можливості оскарження такого виду акта індивідуальної дії.

8. Аналіз судової практики Верховного Суду дає змогу дійти висновку про те, що натепер сформовано судову доктрину, відповідно до якої платник податків уже на етапі здійснення контролюючим органом податкового контролю шляхом інформаційно-аналітичного забезпечення діяльності має спростовувати припущення податкового органу про наявність допущених порушень норм податкового, валютного 
або іншого законодавства, контроль за яким покладається на відповідні органи, наслідком чого є надання фактичної можливості контролюючому органу призначити документальну позапланову перевірку в будь-якому необхідному разі, що не відповідає презумпції правомірності рішень платників податків. Отже, на законодавчому рівні є необхідність визначення більш чітких підстав та критеріїв для призначення відповідного виду перевірки з метою дотримання балансу публічного та приватного інтересів.

9. Індивідуальна податкова консультація є регулятивним актом індивідуальної дії, який, незважаючи на його специфічність, може бути предметом оскарження платником податків у порядку адміністративного судочинства, оскільки створює для платника правовий режим необхідності дотримання роз'яснень податкового законодавства, вказаних у податковій консультації, під загрозою застосування заходів юридичної відповідальності.

\section{Jimepamypa}

1. Конституція України. URL: http://zakon2.rada.gov.ua/laws/show/v0945760-11.

2. Кодекс адміністративного судочинства України (в редакції Закону № 2147-VIII від 03.10.2017 р.). URL: http://zakon3.rada.gov.ua/laws/show/2747-15.

3. Податковий кодекс України від 02.12.2010 p.№ 2755-VI (із наступними змінами та доповненнями). URL: http://zakon4.rada.gov.ua/laws/show/2755-17.

4. Рішення Конституційного Суду України від 23.06.1997 року № 2-зп (справа № 3/35-313). URL: http://zakon.rada.gov.ua/laws/show/v002p710-97.

5. Рішення Конституційного Суду України від 16.04.2009 р.№ 7-рп/2009 (справа № 1-9/2009). URL: http://zakon.rada.gov.ua/laws/show/v007p710-09.

6. Постанова Верховного Суду України від 24.01.2006 p. URL: http://zakon.rada.gov.ua/laws/ show/ru/n0019700-06.

7. Постанова Верховного Суду від 06.02.2018 р. у справі № 810/7195/14 (провадження № K/9901/8185/18). URL: http://www.reyestr.court.gov.ua/Review/72089160.

8. Постанова Верховного Суду від 13.02.2018 р. у справі № 804/5402/14 (провадження № K/9901/8259/18). URL: http://www.reyestr.court.gov.ua/Review/72320483.

9. Постанова Верховного Суду 20.02.2018 р. у справі № 813/2617/15 (адміністративне провадження № K/9901/8571/18). URL: http://www.reyestr.court.gov.ua/Review/72367032.

10. Постанова Верховного Суду від 13.03.2018 р. у справі № 804/1113/16 (провадження № K/9901/19326/18). URL: http://www.reyestr.court.gov.ua/Review/72745230.

11. Постанова Верховного Суду від 27.03.2018 р. у справі № 813/2162/17 (провадження № K/9901/5143/18). URL: http://www.reyestr.court.gov.ua/Review/73043337.

12. Постанова Верховного Суду від 02.05.2018 р. у справі № 804/3006/17 (провадження № K/9901/40546/18). URL: http://www.reyestr.court.gov.ua/Review/73737151.

13. Постанова Верховного Суду від 22.05.2018 р. у справі № 820/4605/17 (провадження № K/9901/30642/18). URL: http://www.reyestr.court.gov.ua/Review/74203938.

14. Постанова Верховного Суду 12.06.2018 р. у справі № 814/2168/16 (адміністративне провадження № К/9901/37755/18). URL: http://www.reyestr.court.gov.ua/Review/74645721.

15. Постанова Верховного Суду від 31.07.2018 р. у справі № 820/653/17 (провадження № K/9901/39717/18). URL: http://www.reyestr.court.gov.ua/Review/75644434.

16. Постанова Верховного Суду від 01.08.2018 р. у справі № 804/2071/15 (провадження № K/9901/28754/18). URL: http://www.reyestr.court.gov.ua/Review/75644213.

17. Постанова Верховного Суду від 22.08.2018 р. у справі № 826/7988/17 (провадження № K/9901/2007/18). URL: http://www.reyestr.court.gov.ua/Review/76094635.

18. Постанова Верховного Суду від 22.08.2018р. у справі № 812/1283/17 (адміністративне провадження №K/9901/46056/18). URL: http://www.reyestr.court.gov.ua/Review/76035627. 
19. Постанова Верховного Суду від 04.09.2018 р. у справі № 810/3676/14 (адміністративне провадження № K/9901/4502/18). URL: http://www.reyestr.court.gov.ua/Review/76246266.

20. Постанова Верховного Суду від 18.09.2018 р. у справі № 820/15224/14 (адміністративне провадження №K/9901/9298/18). URL: http://www.reyestr.court.gov.ua/Review/76543509.

21. Постанова Верховного Суду 16.10 .2018 р. у справі № 820/4461/17 (провадження № K/9901/3725/17). URL: http://www.reyestr.court.gov.ua/Review/77160281.

22. Постанова Верховного Суду від 23.10.2018 р. у справі № 822/1817/18 (адміністративне провадження № K/9901/62472/18). URL: http://www.reyestr.court.gov.ua/Review/77361051.

23. Постанова Верховного Суду від 07.11.2018 р. у справі № П/811/824/17 (адміністративне провадження № K/9901/31381/18). URL: http://www.reyestr.court.gov.ua/Review/77665203.

24. Постанова Верховного Суду від 27.11.2018 р. у справі № 821/1759/17 (адміністративне провадження № К/9901/63522/18). URL: http://www.reyestr.court.gov.ua/Review/78159873.

25. Постанова Верховного Суду від 04.12.2018 р. № 821/1173/17 (адміністративне провадження № K/9901/62719/18). URL: http://www.reyestr.court.gov.ua/Review/78326524.

26. Постанова Верховного Суду від 28.02.2019 р. у справі № 820/4437/18 (провадження № K/9901/66147/18). URL: http://www.reyestr.court.gov.ua/Review/80198217.

27. Гетманцев Д.О., Коваль Ю.А., Нечай М.В. Адміністрування податкових платежів: проблеми теорії та практики : науково-практичний посібник. Київ : Юрінком Інтер, 2017. 776 с.

28. Гетманцев Д.А. Построить Цюрих у себя. Зеркало недели. 2018. вып. 26 (7-13 июля). URL: https://zn.ua/business/postroit-cyurih-u-sebya-288489_.html.

29. Желтобрюх І.Л. Розсуд у податковому правозастосуванні : дис. ... канд. юрид. наук : спец. 12.00.07 «Адміністративне право і процес; фінансове право; інформаційне право». Національний університет Державної податкової служби України. Ірпінь, 2016. 201 с.

30. Кіценко В.С. Правова природа податкових спорів в України : автореф. дис. ...канд. юрид. наук : спец. 12.00.07 «Адміністративне право і процес; фінансове право; інформаційне право». Національний університет «Одеська юридична академія». Одеса, 2010. 20 с.

31. Кучерявенко М.П. Податкові процедури: правова природа та класифікація : монографія. Київ : Алерта; КНТ; ЦУЛ, 2009. 460 с.

32. Лученко Д.В. Механізм оскарження в адміністративному праві: теоретичні й прикладні аспекти : монографія. Харків : Право, 2017. 440 с.

33. Мандюк 0.О. Індивідуальні адміністративні акти: теорія та практика застосування : дис. ... канд. юрид. наук : спец. 12.00.07 «Адміністративне право і процес; фінансове право; інформаційне право». Національний університет «Львівська політехніка». Львів, 2017. 214 с.

34. Небесна М.О. Класифікація адміністративних актів контролюючих органів у сфері оподаткування. Вчені записки Таврійського національного університету імені В.І. Вернадського. Серія «Юридичні науки». 2018. № 4 (том 29). С. 120-125.

35. Порядок надіслання контролюючими органами податкових повідомлень-рішень платникам податків, затверджений наказом Міністерства фінансів України від 28.12.2015 р. № 1204 (зареєстрований у Міністерстві юстиції України 22.01 .2016 р. за № 124/28254) (із наступними змінами): URL: http://zakon.rada.gov.ua/laws/show/z0124-16.

36. Порядок оформлення результатів документальних перевірок дотримання законодавства України з питань державної митної справи, податкового, валютного та іншого законодавства платниками податків - юридичними особами та їх відокремленими підрозділами, затверджений наказом Міністерства фінансів України від 20.08.2015 р. № 727 (зареєстрований у Міністерстві юстиції України 26.10.2015 р. за № 1300/27745) (із наступними змінами): URL: http://zakon.rada.gov.ua/laws/show/z1300-15.

37. Самсін І.Л. Юридичні факти в механізмі вирішення податково-правового спору. Вісник Вищої кваліфікаційної комісії суддів України. 2013, № 2. С. 4-7.

38. Скакун О.Ф. Теорія права і держави : підручник. 4-те видання. Київ : Алерта, 2017. 528 с.

39. Тимощук В.П. Адміністративні акти: процедура прийняття та припинення дії : монографія. Київ : «Конус-Ю», 2010. 296 с.

40. Усенко Є.А. Правове регулювання процедур вирішення податкових спорів: монографія. Харків : Право, 2011. 184 с.

41. Цвіра Д.М. Адміністративне судочинство у справах, пов'язаних із вирішенням податкових спорів : дис. ...канд. юрид. наук : спец. 12.00.07 «Адміністративне право і процес; фінансове право; інформаційне право». Тернопільський національний економічний університет. Тернопіль, 2018. 247 с. 


\section{Анотація}

Слолов $\boldsymbol{K}$. В. Оскарження платником податків рішень контролюючих органів у судовому порядку: окремі теоретичні та практичні проблеми. - Стаття.

У статті досліджуються особливості предмета оскарження у податкових спорах, проблемні питання оскарження окремих категорій рішень та дій контролюючих органів на прикладі податкових повідомлень-рішень, наказів про призначення документальних перевірок та індивідуальних податкових консультацій, розкривається недосконалість структури податкового повідомлення-рішення, межі дискреції контролюючого органу під час здійснення заходів податкового контролю, актуальні питання ефективності способу захисту прав платників податків.

Ключові слова: податкове повідомлення-рішення, акт перевірки, наказ про проведення перевірки, індивідуальна податкова консультація, запит контролюючого органу про надання пояснень та їх документального підтвердження, індивідуальний адміністративний акт, рішення контролюючого органу, податковий спір.

\section{Аннотация}

Смолов К. В. Обжалование налогоплательщиком решений контролирующих органов в судебном порядке: отдельные теоретические и практические проблемы. - Статья.

В статье исследуются особенности предмета обжалования в налоговых спорах, проблемные вопросы обжалования отдельных категорий решений и действий контролирующих органов на примере налоговых уведомлений-решений, приказов о назначении документальных проверок и индивидуальных налоговых консультаций, раскрывается несовершенство структуры налогового уведомления-решения, границы дискреции контролирующего органа в осуществлении мероприятий налогового контроля, актуальные вопросы эффективности способа защиты прав налогоплательщиков.

Ключевые слова: налоговое уведомление-решение, акт проверки, приказ о проведении проверки, индивидуальная налоговая консультация, запрос контролирующего органа о предоставлении объяснений и их документального подтверждения, индивидуальный административный акт, решение контролирующего органа, налоговый спор.

\section{Summary}

Smolov K. V. Appeals by the taxpayer to the decisions of the controlling bodies in court: some theoretical and practical problems. - Article.

The article examines the peculiarities of the subject of appeal in tax disputes, the problematic issues of challenging certain categories of decisions and actions of controlling bodies on the example of tax reports, decisions on the appointment of documentary audits and individual tax consultations, discloses the imperfection of the structure of the tax notice-decision limits the discretion of the controlling authority under time of implementation of tax control measures, actual issues of effectiveness of the method of protecting the rights of taxpayers.

Key words: tax notice-decision, act of verification, order on conducting of audit, individual tax consultation, request of the supervising body for providing explanations and their documentary confirmation, individual administrative act, decision of the controlling body, tax disputes. 